NBER WORKING PAPER SERIES

\title{
RELIGION, POLITICIAN IDENTITY AND DEVELOPMENT OUTCOMES: EVIDENCE FROM INDIA
}

\author{
Sonia R. Bhalotra \\ Guilhem Cassan \\ Irma Clots-Figueras \\ Lakshmi Iyer \\ Working Paper 19173 \\ http://www.nber.org/papers/w19173 \\ NATIONAL BUREAU OF ECONOMIC RESEARCH \\ 1050 Massachusetts Avenue \\ Cambridge, MA 02138 \\ June 2013
}

\begin{abstract}
We are grateful to seminar participants at the ASSA meetings (especially our discussant Ugo Troiano), the NBER Conference on the Economics of Religion and Culture and Oxford University for helpful suggestions. We thank Peter Gerrish, Guillaume Pierre, Maya Shivakumar and Paradigm Data Services for excellent research assistance, and Bradford City Council for sharing software used to decode religion from name. This research was funded by Harvard Business School and the International Growth Centre. Irma Clots-Figueras gratefully acknowledges financial support from SEJ2007-67436 and ECO201129762. The views expressed herein are those of the authors and do not necessarily reflect the views of the $\mathbb{N}$ ational Bureau of Economic Research.
\end{abstract}

NBER working papers are circulated for discussion and comment purposes. They have not been peerreviewed or been subject to the review by the NBER Board of Directors that accompanies official NBER publications.

(C) 2013 by Sonia R. Bhalotra, Guilhem Cassan, Irma Clots-Figueras, and Lakshmi Iyer. All rights reserved. Short sections of text, not to exceed two paragraphs, may be quoted without explicit permission provided that full credit, including $\odot$ notice, is given to the source. 
Religion, Politician Identity and Development Outcomes: Evidence from India Sonia R. Bhalotra, Guilhem Cassan, Irma Clots-Figueras, and Lakshmi Iyer NBER Working Paper No. 19173

June 2013

JEL No. H41,I15,J13,P16

\begin{tabular}{|c|c|}
\hline \\
\hline \multicolumn{2}{|c|}{$\begin{array}{l}\text { ABSTRACT } \\
\text { This paper investigates whether the religious identity of state legislators in India influenc } \\
\text { outcomes, both for citizens of their religious group and for the population as a whole } \\
\text { politician identity to be correlated with constituency level voter preferences or char } \\
\text { make religion salient, we use quasi-random variation in legislator identity generated by } \\
\text { between Muslim and non-Muslim candidates. We find that increasing the political re } \\
\text { Muslims improves health and education outcomes in the district from which the legisl } \\
\text { We find no evidence of religious favoritism: Muslim children do not benefit more from } \mathrm{N} \\
\text { representation than children from other religious groups. }\end{array}$} \\
\hline $\begin{array}{l}\text { Sonia R. Bhalotra } \\
\text { Department of Economics } \\
\text { University of Bristol } \\
8 \text { Woodland Road } \\
\text { Bristol BS8 1TN, UK } \\
\text { s.bhalotra@bristol.ac.uk }\end{array}$ & $\begin{array}{l}\text { Irma Clots-Figueras } \\
\text { Universidad Carlos III de Madrid } \\
\text { Economics Department } \\
\text { C/Madrid } 126 \\
28903 \text { Getage } \\
\text { Madrid } \\
\text { irmaclots@gmail.com }\end{array}$ \\
\hline $\begin{array}{l}\text { Guilhem Cassan } \\
\text { University of Namur, CRED } \\
8 \text { rue du Rempart de la Vierge, } \\
5000 \text {, Namur, Belgium } \\
\text { guilhem.cassan@ fundp.ac.be }\end{array}$ & $\begin{array}{l}\text { Lakshmi Iyer } \\
\text { Harvard Business School } \\
\text { Soldiers Field } \\
\text { Boston, MA } 02163 \\
\text { liyer@hbs.edu }\end{array}$ \\
\hline
\end{tabular}




\section{Introduction}

In first past the post electoral systems where the "winner takes all", minority social groups may be disadvantaged by policy choices made by democratically elected leaders. It is therefore pertinent to consider whether increasing the political representation of minority groups improves their outcomes. Theoretical models of democracy admit this possibility (Osborne and Slivinski 1996, Besley and Coate 1997) and quotas for minority groups are motivated by the assumption that it does but, as we discuss below, the evidence is still scarce. ${ }^{1}$ We examine this question by looking at the impact of Muslim representation in India's state legislatures on development outcomes for Muslims relative to others. This study is of topical relevance given the increasing politicization of religion in India and the frequency of Hindu-Muslim violence.

Muslims are, on many fronts, as disadvantaged a minority group in India as the lower caste population. Yet while political quotas for the lower castes have been in place since the writing of the Indian constitution, there are no quotas for Muslims and no systematic data on their political representation. We create representative nationwide data on Muslim political participation, inferring religion from name. These data show that Muslims are under-represented in state government relative to their population share. To identify causal impacts of politician identity when electoral outcomes may in general be correlated with constituency level voter preferences or events that make religion salient, we exploit close elections between Muslim and non-Muslim (primarily Hindu) politicians. This allows us to examine the effects of politician identity while holding voter identity constant. We isolate the policy consequences of the religion of legislators from their political party affiliation by controlling for party affiliation.

We find that raising the share of Muslims elected from a district to the state legislature leads to improved health and education outcomes in the district. An increase in Muslim representation by 1 percentage point results in a statistically significant decline in infant mortality of 0.148 percentage points on average, which is $1.8 \%$ of the sample mean, and a more imprecisely determined increase of 0.09 years of primary schooling, which is approximately $2.5 \%$ of the sample mean. So as to put a 1 percentage point change in perspective, note that the mean of Muslim legislator share at the district level is $6.4 \%$ and the mean of Muslim population share is $12.9 \%$. $^{2}$ Our estimates therefore

\footnotetext{
${ }^{1}$ Quotas introduce distortions, for instance by lowering candidate quality, so the impact of quotas will in general not be the same as the impact of competitively determined representation. However, evidence of the impact of minority groups in government in the absence of quotas is relevant to motivating quotas.

2 The median district in the sample has nine seats so, on average, less than one in nine seats is held by a Muslim. There is considerable geographic variation in the number of seats (constituencies) per district, the
} 
imply that Muslim representation proportional to population share will have large beneficial impacts on child development outcomes.

Importantly, we find no significant difference in the impact of Muslim political representation on Muslim compared with non-Muslim households. Indeed, the estimated coefficients indicate smaller beneficial impacts for Muslim children. There is thus no evidence of religious favoritism. The fact that our estimates for health and education use different data sources and a different set of cohorts but line up on both results adds credence to the findings.

Our findings contribute to a recent literature on the relationship between religion and development. While cross-country comparisons indicate that religious beliefs are a significant determinant of economic growth, and that Muslim countries have lower growth rates controlling for their religiosity (Barro and McCleary 2006), two recent studies show that Islamist parties perform better than non-Islamist parties. Meyersson (2013) shows that women's education improves in municipalities led by Islamist as opposed to secular parties in Turkey, and Henderson and Kuncoro (2011) find that Islamist parties commit less corruption in Indonesia than other parties. ${ }^{3}$ An important difference between our approach and that of prior studies is that we focus on the personal religious identity of legislators and control for the religious composition of the population and the party affiliation of legislators.

This paper also contributes to the literature on politician identity. If parties could fully control the behaviour of elected candidates, candidate identity would be irrelevant to the policy process but the evidence tends to reject this tenet. The evidence so far pertains to the relevance of the ethnicity and gender of politicians, and we provide the first evidence for religion. A number of studies show that raising the share of women in government influences policy choices, with a tendency for policy choices to more closely reflect the interests of women (Chattopadhyay and Duflo 2004, Washington 2008, Clots-Figueras 2011, Clots-Figueras 2012, Bhalotra and ClotsFigueras 2013, Brollo and Troiano 2012, Iyer et. al. 2012). However women are not a numerical minority. This makes it easier to associate the impact of politician gender with preferences, while the behaviour of politicians from minority groups may in addition reflect strategic electoral considerations. The results on ethnic identity of politicians are more ambiguous. Using data from Kenya, Burgess et al. (2011) find that politicians (cabinet members) allocate road building efforts in

share of Muslim legislators and Muslim population share. The figures presented here are for the estimation sample and exclude the only Muslim-majority state, Jammu and Kashmir.

${ }^{3}$ In work in progress we investigate whether Muslim political representation exacerbates or narrows gender differentials in education and survival (Bhalotra, Cassan, Clots-Figueras and Iyer 2013). 
favour of their own ethnic group but this ethnic favoritism dissipates upon the transition to democracy. In this way, their results are consistent with our findings from (democratic) India. Pande (2003) finds that political quotas for low caste populations in India's state assemblies are associated with increased transfers to their group alongside reduced overall spending and reduced spending on education. ${ }^{4}$ These results contrast with ours, possibly because quotas depress any incentive for the low caste (Hindu) population to serve the interests of other social groups. Kramon and Posner (2012) find that co-ethnics of the President and the Minister of Education in Kenya see an increase in education but not in health. Similarly, Kudamatsu (2009) is unable to identify any impact of the ethnic identity of the President of Guinea on ethnic differences in infant mortality. Again, our results contrast with these studies because we find similar effects on both health and education outcomes.

The rest of the paper is organized as follows: Section 2 reviews the political setting in India, the political status of Muslims and their relative status on human development indicators. Sections 3 and 4 describe the data and the empirical strategy. Section 5 presents and discusses the results and Section 6 concludes.

\section{Religion, Politics and Development in India}

India is a country of considerable religious diversity and the constitution enshrines secularism. Muslims, constituting 13.4\% of the population in the 2001 census, form the single largest religious minority in India. With 138 million Muslims in 2001, India had the third largest Muslim population in the world. Muslims in India are more likely to live in urban areas $(36 \%$ compared to $28 \%$ ), and their population share varies substantially across the states and within states across districts. They are, on average, poorer than Hindus: 31\% of Muslims were below the poverty line in 2004-05, much higher than the figure of $21 \%$ for upper-caste Hindus and comparable to the figure of $35 \%$ for lower castes (Government of India 2006). Yet, while India has political quotas for low caste representation in state assemblies and local governments, there are no quotas for Muslims. ${ }^{5}$ Using newly coded data, described below, we find that Muslims comprised only $9 \%$ of the members of state assemblies over the period 1977-1998, substantially lower than their population share.

\footnotetext{
4 Similarly, Besley, Pande and Rao (2012) find evidence from Indian villages that sharing the village head's group identity is beneficial for access to public goods but only for low spillover public goods.

${ }^{5}$ See Jensenius (2013) for a discussion of the historical reasons underlying the lack of electoral quotas for Muslims.
} 
India is a federal country in which the constitution grants substantial policy autonomy to the 28 states. Elections to state legislatures are held every five years on a first-past-the-post basis in singlemember constituencies. There are very few "Muslim-only" parties, but some parties appeal more to Muslims than others. Indian states largely determine their own health and education budgets, although they receive supplementary funds from federal programs.

Overall health and education outcomes are poor in India, largely a function of weak provision of public services in these sectors. In our household survey data from 1977-1998, 22\% of respondents were illiterate and $8.2 \%$ of children did not survive beyond the first year of life (Table 1). Consistent with their greater poverty rates, Muslims lagged behind on education outcomes, with $27 \%$ of Muslims being recorded as illiterate compared to $21 \%$ of non-Muslims. Yet, Muslim children exhibit a substantial survival advantage (infant mortality rates of $6.86 \%$ compared to $8.42 \%$ for nonMuslims), a bit of a puzzle given that Muslims are, on average, less educated, poorer and have larger families (Bhalotra, Valente and van Soest 2010). Muslim households also faced discrimination in obtaining government loans and pensions (Government of India 2006), and in access to infrastructure, health and transport facilities (Das, Kar and Kayal 2011). Violence between Hindus and Muslims occurs frequently and there is some evidence that an increase in Muslim incomes relative to Hindu incomes often triggers such violence (Mitra and Ray 2013).

\section{Data}

\subsection{The Religious Identity of Candidates for State Legislative Assemblies}

We construct a unique data base on the religious identity of candidates for state legislators. We obtained data on state legislative elections from the Election Commission of India that contain information on the name, party affiliation and votes obtained by every candidate in every state election held in India since Independence. We infer religious identity from candidate names. To minimize measurement error, we had two independent teams conduct the classification of legislator names. The first used software called Nam Pehchan (which translates as Name Recognition) which was able to classify about $72 \%$ of the names, and it manually classified the rest. The second (India-based) team performed the entire classification manually using their judgment gained from prior work with Election Commission files. The two teams agreed on more than 95\% of the names, and disagreements between the two teams' classification were resolved by the authors on a case-by-case basis. In the final dataset, we remained doubtful of the religious identity of less than $0.5 \%$ of names and these were assigned a "non-Muslim" classification. 
The political data are available at the candidate and constituency level, but in the surveys that record individual level health and educational outcomes we can only identify the district, not the constituency, in which they live. We therefore aggregate the political data to the district level using administrative district boundaries as of 1991. The number of electoral constituencies per administrative district varies, but the median district has 9 constituencies and $95 \%$ of districts have 17 or fewer constituencies. We use data from the 16 largest states in India (excluding Jammu and Kashmir), during the period 1977-1998. The rationale for starting the analysis in 1977 and not earlier is twofold. First, during this period, state constituency boundaries remained fixed while before 1977 the number of constituencies increased over time due to periodic redistricting. This could affect our identification strategy because the fraction of Muslim legislators in a district could depend on factors other than whether they won elections, such as population changes or religion-biased redistricting. Second, the set of political parties was very different in the 1960s and 1970s, in particular, the Hindu nationalist party, the Bharatiya Janata Party (BJP), did not exist before 1980. In any case, we show that our results are robust to extending the data back in time to include cohorts from 1961 onwards. The availability of health and educational data with clear district identifiers limits us from extending the analysis beyond 1998. The only Muslim-majority state of Jammu \& Kashmir is excluded from our main regression specification, but we show that our results are robust to its inclusion. District means of the electoral variables are in Table 1, Panel C. In the estimation sample excluding Jammu and Kashmir, 6.4\% of legislators were coded as Muslim, and 64\% of district-year observations had no Muslim legislators.

\subsection{Health Indicators}

Health indicators at the mother and child level are drawn from the National Family Health Survey of India (NFHS), a nationally representative survey conducted in 1998-1999. Mothers aged 15-49 years at the time of the survey are asked to record their birth histories and any child deaths. This allows us to construct individual level childhood mortality risk indicators that vary over time and can be matched to changes in Muslim representation over time. We focus on neonatal and infant mortality, defined as dummies for whether the child died in the first month and the first year of life respectively. Infant mortality is widely used as an indicator of population health. Since infant and neonatal mortality respond primarily to policies effective in the year before birth, we match these individual outcomes to the share of Muslim politicians in the year before birth in the district of birth. Since the data record district of residence rather than district of birth, we restrict the sample to 
children who were conceived in their current location. ${ }^{6}$ The neonatal mortality in the sample is $5.3 \%$, the infant mortality rate is $8.2 \%$ and $14 \%$ of births in the sample take place in a Muslim household (Table 1, Panel A).

\subsection{Education Indicators}

These data are drawn from the $55^{\text {th }}$ round of the nationally representative National Sample Survey (NSS), collected during 1999-2000. We restrict attention to individuals aged 14 and older, to be sure that they are old enough to have completed primary education, and the oldest individual in the education sample is 26 . We create two dependent variables to indicate whether the individual is illiterate and the number of years of primary education completed. The data contain information on whether the individual has completed primary or has dropped out before finishing primary education. As in Hnatkovska et al (2012), we create the "years of primary education" variable by assigning the value 0 to illiterate individuals, 2 to those who started but did not complete primary education, and 5 to those who completed primary. ${ }^{7}$ On average, $22 \%$ of individuals in the sample are illiterate and average years of primary education are 3.67.

Only politicians in power before the child completed primary education can affect the likelihood of completing it. Since individuals vary in the age at which they start school, we matched individuals to legislator identity in the three years leading up to their primary school participation. We investigate this and implement a placebo using timing. Although cross-district migration in India is small, we drop from the sample individuals who migrated from another district after they were six years old as they will have studied in districts in which other politicians were in power.

\section{Empirical Strategy}

To investigate the effect of the religious identity of politicians on health and educational outcomes, we would like to estimate the parameters of the relationship:

$$
Y_{i d s t}=a+b M_{d s t}+e_{i d s t}
$$

\footnotetext{
${ }^{6}$ Approximately $16 \%$ of the survey respondents moved to their current area of residence after the child was conceived.

${ }^{7}$ Given the timing of elections (post-1980) and the duration of secondary education, we do not have enough cohorts in the 1999 survey to examine secondary education. We focus therefore upon primary education which, for the cohorts in the sample, is far from universal, see Table 1.
} 
where $Y_{\text {idst }}$ is the health or education outcome for individual $i$ born in district $d$ in state $s$ in year $t$, and $M_{d s t}$ is the fraction of constituencies in the district held by Muslim politicians in the year before birth for survival outcomes and in the three years before the individual turned six for the education outcomes. The identification challenge is to estimate a causal relationship by separating this from any effects of omitted variables that may drive health/education and religious political representation.

We address this challenge by using close elections between non-Muslim and Muslim candidates, that is, elections in which the difference in votes between the winner and the runner-up (the vote margin) is small. The outcome of elections in which the vote difference between the two candidates is small is regarded as quasi-random because the vote margin that determines the winner will tend to be determined by chance elements, such as marginal changes in turnout associated for instance with the weather on the day the election take place. This ensures that Muslim candidates who barely win an election against non-Muslims do so in constituencies where there is no clear underlying preference for Muslim politicians since the non-Muslim politician is just as likely to have won. On this basis we instrument the fraction of all seats in a district won by Muslim politicians with the fraction of seats in the district won by Muslim politicians in a close election against a nonMuslim politician. We define close elections as elections in which the winner won by a margin of less than $2 \%$ of votes, and we investigate robustness of the results to using a $3 \%$ margin instead.

Even if the outcome of close elections can be considered essentially random, the existence of close elections between Muslims and non-Muslims in a given district and year is unlikely to be random, and is likely to be depend upon the share of Muslims in the population, their relative status and the extent to which religion is politicized in the region. We therefore control for the fraction of seats in the district that were contested in close elections between Muslim and non-Muslim candidates. This also controls for any direct effects of having close elections, such as greater political mobilization by parties or greater salience generated by the "excitement" of a close contest.

At the constituency level, close elections can be exploited to implement a regression discontinuity design. Since the share of Muslim legislators is defined at the district level (in order to match the electoral data to health and education outcomes), we effectively aggregate over the constituency-specific discontinuities in treatment assignment within district, in the spirit of a fuzzy regression discontinuity. The estimated equations control for a polynomial in the victory margin (positive or negative) in every election between a Muslim and a non-Muslim candidate in the district. 
The model is estimated using two-stage least squares. Here, equation (1) is the second stage and equation (2) is the first stage:

$$
\begin{gathered}
Y_{i d s t}=\theta_{d s}+\psi_{t}+\pi_{s t}+\beta M_{d s t}+\lambda T C_{d s t}+\sum_{j=1}^{N} a_{1 j} I_{j d s t}{ }^{*} G\left(m_{j d s}\right)+\sum_{j=1}^{N} a_{2 j} I_{j d s t}+X_{i d s t} \eta+\varepsilon_{i d s t} \\
M_{d s t}=\theta_{d s}+\psi_{t}+\pi_{s t}+x M C_{d s t}+\mu T C_{d s t}+\sum_{j=1}^{N} \vartheta_{1 j} I_{j d s t}^{*} G\left(m_{j d s t}\right)+\sum_{j=1}^{N} \vartheta_{2 j} I_{j d s t}+X_{i d s t} \sigma+u_{i d t}
\end{gathered}
$$

The fraction of constituencies in the district that were won by Muslim politicians in a given election year, $M_{d s}$ is instrumented with the fraction of constituencies in the district won by Muslims in close elections against non-Muslim in the same year, $M C_{d s s^{*}}$ The fraction of constituencies in the district in which there were close elections between Muslims and non-Muslims, $T C_{d s}$ is controlled for in equation (1) and partialled out of the instrument in equation (2). The margin of victory or defeat of every Muslim candidate who contested against a non-Muslim in election $j$ in the district is denoted $m_{j d s t}$. We use third order polynomials in these margins, denoted $\mathrm{G}\left(m_{j d s t}\right)$. The polynomials are interacted with $I_{j d s}$, which is an indicator for whether there was an inter-religious election in the district. To allow observations in a district to be correlated across families in the district and across time, the standard errors are clustered at the district level.

Our baseline specification uses district fixed effects $\theta_{d s}$ which account for sluggish demographic characteristics (including the share of the district population that is Muslim), the slowly moving component of the public goods infrastructure and time-invariant voter preferences. Cohort fixed effects $\psi_{t}$ afford a flexible representation of aggregate shocks or nationwide policies that through changes in income or in religious identification, for instance, may have influenced both public services and the religion mix of politicians. We also include state*cohort dummies, $\pi_{s,}$, which account for relevant state-level and election-specific shocks or policies. $X_{i d s t}$ is a vector of individuallevel control variables including dummies for individual religion, gender, rural vs urban residence and whether the individual belongs to a scheduled caste or tribe (which we loosely refer to as "low caste") or to the "Other Backward Castes". Given that Muslim winners in close elections are more likely to belong to the Indian National Congress (INC) party than non-Muslim winners and less likely to belong to the BJP party (Table A4), we control for the fraction of seats in the district won by INC and the BJP.

Regression discontinuity has been previously used in the context of elections by Lee (2002) who studies incumbency advantage, by Pettersson-Lidbom (2008) who looks at the effect of party 
control on fiscal policies and by Lee, Moretti and Butler (2004) who estimate the effect of the degree of electoral strength on legislators' voting behavior. Our approach of using an IV strategy approximating a fuzzy regression discontinuity has antecedents in the work of Angrist and Lavy (1999) who estimated the effect of class size on educational achievements and the work of Rehavi (2007), Clots-Figueras (2011 and 2012) and Bhalotra and Clots-Figueras (2013), who estimate related specifications to investigate the policy impact of the gender of elected politicians.

To investigate whether Muslims in particular gain from a rise in the share of Muslim politicians, we interact $M_{d s t}$ (Muslim legislator share) with an indicator for whether the individual child is Muslim. To implement the IV procedure, we also interact the instrument with the Muslim dummy. The second stage regression is then:

$$
Y_{i d s t}=\theta_{d s}+\psi_{t}+\pi_{s t}+\beta M_{d s t}+\gamma M_{d s t}{ }^{*} \text { muslimidst }+\xi \text { muslimidst }_{i d s}+\lambda T C_{d s t}+\sum_{j=1}^{N} a_{1 j} I_{j d s t}{ }^{*} G\left(m_{j d s t}\right)+\sum_{j=1}^{N} a_{2 j} I_{j d s t}
$$

$+X_{i d s t} \eta+\varepsilon_{i d s t}$

The coefficient $\gamma$ indicates the differential between Muslim and non-Muslim children while the coefficient $\beta$ captures the effect for non-Muslims.

\section{Muslim Political Representation and Development Outcomes}

\subsection{Validity of the Instrumental Variable Strategy}

The share of Muslims winning close elections against non-Muslims is a strong and significant predictor of the overall fraction of Muslim legislators in a district (Table A2). The F-statistics from the first stage regressions shown in Table A2 are large for regressions run at the individual and district levels, so we can rule out a weak instruments problem (the district results are available upon request). Figure 1 provides a graphical illustration of the first stage. It plots the overall fraction of Muslim legislators against the average vote margin across districts. The victory margin is defined as the difference in vote share between Muslim and non-Muslim candidates, so that margin $>0$ denotes a Muslim electoral victory and margin $<0$ denotes a non-Muslim victory. We show that, at the zero margin, there is a dramatic jump in the district share of Muslim legislators. In other words, if a Muslim wins a close election, the overall fraction of Muslim legislators rises significantly.

As discussed earlier, our instrumental variables strategy is based on the assumption that the results of close elections are quasi-random. A potential violation of this assumption would arise if there were vote manipulation that biased the outcome of a close election. To check against this 
possibility, we verify that the distribution of the vote margin is continuous around the neighbourhood of zero, the threshold which separates Muslim victory from non-Muslim victory (Figure 2a). We tested this formally by estimating the difference in the densities on either side of the zero point (McCrary 2008). The estimated difference is -0.065 , which is statistically insignificant (Figure 2b).

Another possible threat to our identification strategy arises if Muslim legislators who win in close elections against non-Muslims are significantly different from non-Muslims along dimensions other than religion because we might then mistakenly attribute the effects of other characteristics to religious identity. We therefore examine available characteristics of Muslim and non-Muslim winners in close elections (Table A4). Muslim winners are significantly less likely to belong to the Bharatiya Janata Party (BJP), the party espousing a pro-Hindu ideology, and more likely to belong to the Indian National Congress (INC). Since we want to capture the effects of religious identity rather than party ideology, we control for the overall fraction of BJP and INC legislators in the district. Membership of other parties (Left parties, other regional parties, independents) is not significantly different by candidate religion. Muslim legislators are less likely to be female than non-Muslim legislators $(2 \%$ compared to $5.4 \%)$, but the difference is not statistically significant. We also verify that election characteristics, such as the total number of candidates and the total number of voters, do not differ significantly across places where Muslims win vs lose close elections against nonMuslims.

\subsection{Estimating the Impact of Muslim Legislators on Development Outcomes}

We find that raising the share of Muslim legislators in the district leads to a large and statistically significant decline in infant and neonatal mortality rates. Table 2 shows the results of estimating equation (1), with increasing number of controls (columns 1-3, 4-6). In the preferred specification (column 3), which includes third degree polynomials in constituency vote margins and controls for party composition, we estimate that increasing the share of Muslim legislators by 1 percentage point results in a decline in infant mortality of 0.148 percentage points, which is roughly $1.8 \%$ of the mean rate. $^{8}$ The corresponding decline in the neo-natal mortality rate is 0.11 percentage points, nearly

\footnotetext{
${ }^{8}$ There are 9 legislators in the median district and the mean share of Muslim legislators in the sample is 6.4\% (s.d. 13\%). To put the $1 \%$ point changes in perspective note that increasing the share of Muslim legislators by $10 \%$ points is roughly equivalent to adding one Muslim legislator to the median district, and not dissimilar to an increase of one standard deviation.
} 
$2.1 \%$ of the mean. These estimates suggest substantial "economic" returns to improving the political representation of minority religious groups.

Our second major finding is that these gains in child mortality are concentrated among nonMuslim households. The reduction in infant mortality associated with a $1 \%$ point increase in Muslim representation is 1.16 percentage points among Muslim families compared to 1.58 percentage points among non-Muslims (column 4), but the difference between the two groups is statistically insignificant. The corresponding values for neo-natal mortality are $0.55 \%$ for Muslims and $1.27 \%$ for non-Muslims (column 8). There is thus no evidence that Muslim legislators are targeting public services towards Muslim families.

A potential explanation of this result is that Muslims have stronger preferences over child health (see Bhalotra, Valente and Van Soest 2010) so they prioritise it and the apparently large benefits accruing to non-Muslims represent a process of convergence, since the baseline child survival rates of Muslims are higher. However, we find a similar pattern of results when we examine education outcomes, in which Muslims lag behind non-Muslims (Table 1). Muslim political representation results in a decline in the share of the population which is illiterate and an increase in years of primary school education (Table 3). While the average coefficients are imprecisely estimated, we find significant effects once we allow heterogeneity by religion. Among non-Muslims, the illiteracy rate declines by 0.25 percentage points for a 1 percentage point increase in Muslim political representation (column 4) and years of primary education increase by 0.01 years (column 8). The corresponding effects of Muslim political representation on the educational attainment of Muslims are smaller and statistically indistinguishable from zero.

Taken together, the health and education results show a consistent pattern whereby raising the share of Muslims in India's state assemblies improves developmental outcomes for children, with no evidence of differential benefits flowing to Muslim children.

\subsection{Robustness Checks}

The results reported above stand up to a number of specification checks, presented in Tables 4 (health) and 5 (education). The estimates are robust to expanding the definition of close elections to include elections with a vote margin of up to $3 \%$ (column 1 ). Narrowing to a vote margin of $1 \%$ or less results in similar sized coefficients but we lose precision and the estimates are no longer statistically significant (column 2). The estimates are similar if we control for state-specific trends instead of state*year fixed effects (column 3). The coefficients are also stable in a specification that 
controls for district-specific trends. The relevant variation is at the district level, but this is a much more demanding specification and the standard errors increase, making the overall coefficient statistically insignificant (column 4). Including the Muslim-majority state of Jammu \& Kashmir raises the estimated main effect (column 5). This limits the weight of mechanisms that rest upon Muslims being a minority population group. Extending the sample back to include cohorts from 1961 onwards (column 6) also increases the estimated positive impact of Muslim legislators which is interesting since the politicization of religion was greater in the 1980s and the 1990s. To allow for the possibility that one year may be too soon for a legislator to be effective in changing health outcomes, we replace the presence of a Muslim legislator in the year prior to birth with a variable measuring the average share of Muslim legislators in the three years prior to the birth of the individual child. The coefficient is similar to that in the baseline specification (column 7). In all of these specifications, there continues to be no evidence that Muslim households benefit disproportionately from the presence of a Muslim legislator.

We conducted a "placebo" exercise to verify that it is indeed the presence of Muslim legislators prior to birth which matters for child health outcomes, rather than unobserved area or household characteristics which might be correlated with both child health outcomes and the share of Muslim legislators. We examine whether exposure to Muslim legislators after the first year of life is correlated with child health outcomes. As there is no plausible mechanism to support such a correlation, evidence of it would signal mis-specification. Since legislators typically have a five year term, Muslim representation in the year after birth is likely to be correlated with Muslim representation in the year before birth. We therefore look at Muslim representation five years after birth, during which at least one election would have occurred. The coefficient on Muslim legislator share is much smaller in magnitude and this and the interaction coefficient are both statistically insignificant. The placebo results satisfy us that omitted variables are not driving the main findings (column 8).

The same battery of robustness checks was conducted for the education outcomes and the results are robust to the range of checks (Table 5). The one exception is a reduction in coefficient size when we replace the share of Muslim legislators in the 3 years prior to primary school age with the share of Muslim legislators in the one year prior to joining school (column 7), consistent with legislators needing to be in power longer in order to affect educational outcomes. The "placebo" for education is specified to examine whether the presence of Muslim legislators matters for children who are exposed after the age of completion of primary schooling (Table 5, column 8). The estimated coefficient is much smaller and statistically insignificant. 


\section{Conclusions}

We use unique data on the religious identity of politicians, and an instrumental variables strategy based on the discontinuity in treatment assignment in close elections to estimate the causal effect of electing Muslims to state legislatures. We find that raising Muslim representation in India's state legislatures leads to large and significant improvements in child survival rates and improvements in educational attainment. We find no evidence of religious favouritism, if at all, Muslim households benefit less from Muslim politicians than non-Muslim households. The estimates are robust to a number of specification checks, including different sample windows and different margins for defining close elections, and do not appear to be driven by omitted district and time varying unobservables.

Why are Muslim leaders more effective than other (primarily Hindu) leaders at delivering improvements in child health and education? One plausible explanation is that Muslims have stronger preferences over publicly provided services essentially because they are, on average, poorer and so more reliant upon them. However, we might then have expected to see larger gains to Muslim households. So, the preference hypothesis needs to be combined with barriers to targeting benefits to Muslim households in order to explain our results. Perhaps Muslims are not sufficiently residentially segregated for targeting to be feasible, or perhaps there are political incentives for Muslim politicians to avoid showing favor for members of their own group. Muslim leaders may act strategically to attract votes from the non-Muslim community, who constitute the numerical majority in most constituencies. A different possibility, consistent with Muslim leaders representing the interests of Muslim citizens, is that they prioritise reducing Hindu-Muslim conflict, and equal provision of public goods is a means to this end. ${ }^{9}$

\footnotetext{
${ }^{9}$ In work in progress we investigate the impact of Muslim legislators on religious conflict (Bhalotra, ClotsFigueras and Iyer 2013).
} 


\section{References}

Angrist, Joshua and Victor Lavy (1999), "Using Maimonides' Rule to Estimate the Effect of Class Size on Scholastic Achievement", Quarterly Journal of Economics, 114 (2).

Barro, Robert and Rachel McCleary (2006), "Religion and Economy," Journal of Economic Perspectives 20 (2), 49-72.

Besley, Timothy and Steve Coate (1997), "An Economic Model of Representative Democracy," Quarterly Journal of Economics 112 (1).

Besley, Timothy, Rohini Pande and Vijayendra Rao (2012), “Just Rewards? Local Politics and Public Resource Allocation in South India,” World Bank Economic Review 26 (2), 2012.

Bhalotra, Sonia and Irma Clots-Figueras (2013), "Health and the political agency of women." American Economic Journal: Economic Policy, forthcoming.

Bhalotra, Sonia, Irma Clots-Figueras and Lakshmi Iyer (2013), "Religion, Politics and Violence in India," Work in progress.

Bhalotra, Sonia, Guilhem Cassan, Irma Clots-Figueras and Lakshmi Iyer (2013), "Muslim Political Representation and Gender in India," Work in progress.

Bhalotra, S., C Valente and A van Soest (2010), “The Puzzle Of Muslim Advantage In Child Survival In India," Journal of Health Economics.

Burgess, Robin Burgess, Remi Jedwab, Edward Miguel, Ameet Morjaria and Gerard Padro-i- Miquel (2011), “Ethnic Favoritism,” Working Paper.

Brollo, Fernanda and Ugo Troiano (2012) "What Happens When a Woman Wins a Close Election? Evidence from Brazil,” Working Paper.

Chattopadhay, R. \& Duflo, E (2004), "Women as Policy Makers: Evidence from a India-Wide Randomized Policy Experiment," Econometrica, 72(5).

Clots-Figueras, Irma (2011), "Women in Politics: Evidence from the Indian States." Journal of Public Economics 95: 664-690.

Clots-Figueras, Irma (2012), “Are female leaders good for education? Evidence from India." American Economic Journal: Applied Economics.

Das, Pranab Kumar, Saibal Kar and Madhumanti Kayal (2011), "Religious Minorities and Provision of Public Goods: Evidence from Rural West Bengal”. IZA Working Paper 6154.

Government of India (2006), Social, Economic and Educational Status of the Muslim Community of India: A Report. 
Hnatkovska, Viktoria, Amartya Lahiri, and Sourabh B. Paul (2012), "Castes and Labor Mobility," American Economic Journal: Applied Economics.

Iyer, L., A.Mani, P.Mishra and P.Topalova (2012), “The Power of Political Voice: Women’s Political Representation and Crime in India." American Economic Journal: Applied Economics.

Jensenius F. (2013), "Power, Performance and Bias: Evaluating the Electoral Quotas for Scheduled Castes in India". PhD thesis, University of California Berkeley.

Kramon, Eric and Daniel Posner (2012), "Ethnic Favoritism in Primary Education in Kenya". Working Paper.

Kudamatsu, Masayuki (2009), "Ethnic Favoritism: Micro Evidence from Guinea,” Working Paper.

Lee D.S. (2002), "Randomized experiments from non-random selection in U.S. House elections." Journal of Econometrics.

Lee, David S., Enrico Moretti, and Matthew J. Butler. 2004. "Do Voters Affect or Elect Policies? Evidence from the U.S. House". Quarterly Journal of Economics, 119(3), 807-860.

McCrary, Justin (2008), "Manipulation of the Running Variable in the Regression Discontinuity Design: A Density Test," Journal of Economic Literature 142 (2).

Meyersson E. (2013), "Islamic rule and the empowerment of the poor and pious". Working Paper.

Mitra A. and Ray D. (2013), "Implications of an economic theory of conflict: Hindu Muslim Violence in India". Working paper.

Osborne, M.J. and Slivinksy, A. (1996), "A Model of Political Competition with Citizen Candidates," Quarterly Journal of Economics 111, 65-96.

Pande, Rohini (2003), “Can Mandated Political Representation Increase Policy Influence for Disadvantaged Minorities? Theory and Evidence from India," American Economic Review, 93(4).

Pettersson-Lidbom, Per (2008), "Do Parties Matter for Economic Outcomes: A RegressionDiscontinuity Approach," Journal of the European Economic Association 6 (5): 1037-1056.

Rehavi, Marit (2007), “Sex and Politics: Do Female Legislators Affect State Spending?," Working Paper.

Vernon Henderson J. and Kuncoro A. (2011), "Corruption and Local Democratization in Indonesia: The Role of Islamic Parties”. Journal of Development Economics, Vol 94 (2).

Washington, Ebonya (2008), “Female Socialization: How Daughters Affect Their Legislator Fathers' Voting on Women's Issues." American Economic Review 98(1): 311-332. 
Table 1: Summary Statistics

\begin{tabular}{|c|c|c|c|c|c|c|c|}
\hline \multirow{3}{*}{\multicolumn{2}{|c|}{ Panel A: Health and Demographics, Individual data, NFHS 1998-1999, birth cohorts 1977-1998 }} & \multirow[t]{2}{*}{ Mean } & \multirow[t]{2}{*}{ s.d. } & \multicolumn{2}{|l|}{ s.d. } & \multicolumn{2}{|c|}{ Mean } \\
\hline & & & & $\begin{array}{r}\text { Between } \\
\text { district }\end{array}$ & $\begin{array}{l}\text { Within } \\
\text { district }\end{array}$ & $\begin{array}{r}\text { Non-Muslim } \\
\text { households }\end{array}$ & $\begin{array}{r}\text { Muslim } \\
\text { households }\end{array}$ \\
\hline & & & & & & & \\
\hline Infant mortality (scaled 0-100) & 128100 & 8.21 & 27.45 & 3.65 & 27.23 & 8.42 & 6.86 \\
\hline Neonatal mortality (scaled 0-100) & 128100 & 5.29 & 22.38 & 2.56 & 22.25 & 5.41 & 4.49 \\
\hline Rural resident & 128100 & 0.77 & 0.42 & 0.23 & 0.35 & 0.79 & 0.65 \\
\hline Muslim & 128100 & 0.14 & 0.34 & 0.17 & 0.30 & 0.00 & 1.00 \\
\hline Scheduled caste & 128100 & 0.20 & 0.40 & 0.12 & 0.39 & 0.23 & 0.03 \\
\hline Scheduled tribe & 128100 & 0.10 & 0.30 & 0.17 & 0.26 & 0.12 & 0.01 \\
\hline Male child & 128100 & 0.52 & 0.50 & 0.04 & 0.50 & 0.52 & 0.51 \\
\hline Age of mother at birth of child & 128100 & 23.64 & 5.22 & 1.22 & 5.10 & 23.56 & 24.17 \\
\hline Year of education of mother & 128094 & 2.48 & 3.93 & 1.88 & 3.52 & 2.55 & 2.06 \\
\hline Years of education of father & 128100 & 5.29 & 4.82 & 1.77 & 4.55 & 5.46 & 4.19 \\
\hline \multicolumn{8}{|c|}{ Panel B: Education and Demographics, Individual data, NSS 1999-2000, individuals aged 14 or more at survey date } \\
\hline Illiterate & 109448 & 0.22 & 0.42 & 0.14 & 0.39 & 0.21 & 0.27 \\
\hline Years of education up to primary & 109448 & 3.67 & 2.11 & 0.76 & 1.98 & 3.72 & 3.37 \\
\hline Muslim & 109448 & 0.14 & 0.35 & 0.13 & 0.32 & 0.00 & 1.00 \\
\hline Age of mother at birth of child & 109448 & 19.17 & 3.56 & 0.48 & 3.53 & 19.20 & 18.97 \\
\hline Male child & 109448 & 0.54 & 0.50 & 0.05 & 0.50 & 0.54 & 0.53 \\
\hline Scheduled caste & 109448 & 0.08 & 0.27 & 0.15 & 0.23 & 0.09 & 0.01 \\
\hline Scheduled tribe & 109448 & 0.17 & 0.38 & 0.09 & 0.37 & 0.20 & 0.01 \\
\hline Other backward caste (OBC) & 109448 & 0.36 & 0.48 & 0.20 & 0.43 & 0.36 & 0.33 \\
\hline Rural resident & 109448 & 0.63 & 0.48 & 0.21 & 0.43 & 0.66 & 0.49 \\
\hline \multicolumn{8}{|c|}{ Panel C: Electoral Variables. District-year data, Election Commission of India, 1977-1998. } \\
\hline Proportion of seats in the district won by a Muslim politician & 8549 & 0.064 & 0.130 & & & & \\
\hline Proportion seats in the dist won by Muslim in close election against non-Muslim $2 \%$ & 8549 & 0.005 & 0.027 & & & & \\
\hline Proportion seats that had close elections Muslim vs non-Muslim 2\% & 8549 & 0.011 & 0.040 & & & & \\
\hline Proportion seats in the dist won by Muslim in close election against non-Muslim $1 \%$ & 8549 & 0.003 & 0.022 & & & & \\
\hline Proportion seats that had close elections Muslim vs non-Muslim 1\% & 8549 & 0.006 & 0.031 & & & & \\
\hline Proportion seats in the dist won by Muslim in close election against non-Muslim 3\% & 8549 & 0.007 & 0.034 & & & & \\
\hline Proportion seats that had close elections Muslim vs non-Muslim 3\% & 8549 & 0.016 & 0.050 & & & & \\
\hline
\end{tabular}

Notes: The percentages in Panel C refer to the vote margin on either side of zero that is used to define close elections between Muslim and non-Muslim candidates. 
Table 2

Muslim Legislators and Health Outcomes: 2SLS estimates

\begin{tabular}{|c|c|c|c|c|c|c|c|c|}
\hline \multirow[b]{3}{*}{ Fraction Muslim legislators in district } & \multicolumn{4}{|c|}{ Infant mortality } & \multicolumn{4}{|c|}{ Neo-natal mortality } \\
\hline & $(1)$ & $(2)$ & (3) & $(4)$ & $(5)$ & $(6)$ & $(7)$ & $(8)$ \\
\hline & $\begin{array}{c}-15.208^{* *} \\
{[7.313]}\end{array}$ & $\begin{array}{c}-14.397 * * \\
{[6.634]}\end{array}$ & $\begin{array}{c}-14.847 * * \\
{[6.836]}\end{array}$ & $\begin{array}{c}-15.782 * * \\
{[6.954]}\end{array}$ & $\begin{array}{l}-9.854 * \\
{[5.859]}\end{array}$ & $\begin{array}{c}-10.853^{* *} \\
{[5.382]}\end{array}$ & $\begin{array}{c}-11.122 * * \\
{[5.558]}\end{array}$ & $\begin{array}{c}-12.748 * * \\
{[5.454]}\end{array}$ \\
\hline $\begin{array}{l}\text { Fraction close elections between } \mathrm{M} \\
\text { and non-M in district }\end{array}$ & $\begin{array}{c}-1.14 \\
{[2.937]}\end{array}$ & $\begin{array}{c}-2.548 \\
{[2.931]}\end{array}$ & $\begin{array}{c}-2.218 \\
{[2.941]}\end{array}$ & $\begin{array}{l}-2.305 \\
{[2.915]}\end{array}$ & $\begin{array}{c}3.279 \\
{[2.638]}\end{array}$ & $\begin{array}{c}2.817 \\
{[2.673]}\end{array}$ & $\begin{array}{c}3.05 \\
{[2.669]}\end{array}$ & $\begin{array}{c}2.899 \\
{[2.594]}\end{array}$ \\
\hline Fraction Muslim legislators * Muslim household & & & & $\begin{array}{c}4.183 \\
{[9.379]}\end{array}$ & & & & $\begin{array}{c}7.279 \\
{[7.917]}\end{array}$ \\
\hline Muslim household & $\begin{array}{c}-1.301^{* * *} \\
{[0.319]}\end{array}$ & $\begin{array}{c}-1.308 * * * \\
{[0.321]}\end{array}$ & $\begin{array}{c}-1.308 * * * \\
{[0.321]}\end{array}$ & $\begin{array}{c}-1.807 \\
{[1.126]}\end{array}$ & $\begin{array}{c}-0.665 * * * \\
{[0.253]}\end{array}$ & $\begin{array}{c}-0.672 * * * \\
{[0.253]}\end{array}$ & $\begin{array}{c}-0.672 * * * \\
{[0.253]}\end{array}$ & $\begin{array}{l}-1.540^{*} \\
{[0.933]}\end{array}$ \\
\hline R-squared & 0.04 & 0.04 & 0.04 & 0.04 & 0.03 & 0.04 & 0.04 & 0.04 \\
\hline Observations & 128100 & 128100 & 128100 & 128100 & 128100 & 128100 & 128100 & 128100 \\
\hline District and year-of-birth FE & $\mathrm{Y}$ & $\mathrm{Y}$ & $\mathrm{Y}$ & $\mathrm{Y}$ & $\mathrm{Y}$ & $\mathrm{Y}$ & $\mathrm{Y}$ & $\mathrm{Y}$ \\
\hline Party composition of legislators & $\mathrm{N}$ & $\mathrm{N}$ & $\mathrm{Y}$ & $\mathrm{Y}$ & $\mathrm{N}$ & $\mathrm{N}$ & $\mathrm{Y}$ & $\mathrm{Y}$ \\
\hline Margin of victory & $2 \%$ & $2 \%$ & $2 \%$ & $2 \%$ & $2 \%$ & $2 \%$ & $2 \%$ & $2 \%$ \\
\hline
\end{tabular}

*** $\mathrm{p}<0.01,{ }^{* *} \mathrm{p}<0.05, * \mathrm{p}<0.1$. Robust standard errors in parentheses, clustered at district level. All regressions include controls for household characteristics such as dummies for rural residence, Scheduled Caste, Scheduled Tribe, Muslim, Other backward caste, male child, education levels of father and mother, age of mother at birth of child and its square, a dummy for multiple births and the child's birth rank. Regressions exclude the state of Jammu \& Kashmir . 
Table 3

Muslim Legislators and Educational Outcomes: 2SLS estimates

\begin{tabular}{|c|c|c|c|c|c|c|c|c|}
\hline \multirow[b]{3}{*}{ Fraction Muslim legislators in district } & \multicolumn{4}{|c|}{ Illiteracy } & \multicolumn{4}{|c|}{ Years of primary school education } \\
\hline & (1) & $(2)$ & (3) & $(4)$ & (5) & (6) & $(7)$ & (8) \\
\hline & $\begin{array}{c}-0.172 \\
{[0.120]}\end{array}$ & $\begin{array}{c}-0.140 \\
{[0.120]}\end{array}$ & $\begin{array}{c}-0.155 \\
{[0.123]}\end{array}$ & $\begin{array}{c}-0.248^{*} \\
{[0.142]}\end{array}$ & $\begin{array}{c}0.910 \\
{[0.617]}\end{array}$ & $\begin{array}{c}0.856 \\
{[0.614]}\end{array}$ & $\begin{array}{r}0.913 \\
{[0.623]}\end{array}$ & $\begin{array}{c}1.378^{*} \\
{[0.730]}\end{array}$ \\
\hline $\begin{array}{l}\text { Fraction close elections between } \mathrm{M} \\
\text { and non-M in district }\end{array}$ & $\begin{array}{c}0.052 \\
{[0.065]}\end{array}$ & $\begin{array}{c}0.023 \\
{[0.056]}\end{array}$ & $\begin{array}{c}0.029 \\
{[0.057]}\end{array}$ & $\begin{array}{c}0.030 \\
{[0.057]}\end{array}$ & $\begin{array}{r}-0.176 \\
{[0.323]}\end{array}$ & $\begin{array}{r}-0.066 \\
{[0.288]}\end{array}$ & $\begin{array}{r}-0.092 \\
{[0.290]}\end{array}$ & $\begin{array}{r}-0.092 \\
{[0.288]}\end{array}$ \\
\hline Fraction Muslim legislators * Muslim household & & & & $\begin{array}{c}0.382 \\
{[0.290]}\end{array}$ & & & & $\begin{array}{c}-1.904 \\
{[1.381]}\end{array}$ \\
\hline Muslim household & $\begin{array}{l}0.144 * * * \\
{[0.011]}\end{array}$ & $\begin{array}{l}0.144 * * * \\
\quad[0.011]\end{array}$ & $\begin{array}{r}0.144^{* * *} \\
{[0.011]}\end{array}$ & $\begin{array}{l}0.095^{* *} \\
{[0.037]}\end{array}$ & $\begin{array}{r}-0.859 * * * \\
{[0.056]}\end{array}$ & $\begin{array}{r}-0.858 * * * \\
{[0.056]}\end{array}$ & $\begin{array}{r}-0.858 * * * \\
{[0.056]}\end{array}$ & $\begin{array}{r}-0.614^{* * *} \\
{[0.180]}\end{array}$ \\
\hline R-squared & & & & & & & & \\
\hline Observations & 0.22 & 0.22 & 0.22 & 0.22 & 0.24 & 0.24 & 0.24 & 0.24 \\
\hline District and year-of-birth FE & 109448 & 109448 & 109448 & 109448 & 109448 & 109448 & 109448 & 109448 \\
\hline State*year-of-birth FE & $\mathrm{Y}$ & $\mathrm{Y}$ & $\mathrm{Y}$ & $\mathrm{Y}$ & $\mathrm{Y}$ & $\mathrm{Y}$ & $\mathrm{Y}$ & $\mathrm{Y}$ \\
\hline Party composition of legislators & $\mathrm{N}$ & $\mathrm{N}$ & $\mathrm{Y}$ & $\mathrm{Y}$ & $\mathrm{N}$ & $\mathrm{N}$ & $\mathrm{Y}$ & $\mathrm{Y}$ \\
\hline Margin of victory & $2 \%$ & $2 \%$ & $2 \%$ & $2 \%$ & $2 \%$ & $2 \%$ & $2 \%$ & $2 \%$ \\
\hline
\end{tabular}

*** $\mathrm{p}<0.01,{ }^{* *} \mathrm{p}<0.05, * \mathrm{p}<0.1$. Robust standard errors in parantheses, clustered at district level. All regressions include controls for household characteristics such as dummies for rural residence, Scheduled Caste, Scheduled Tribe, Muslim, Other backward caste, male. Regressions exclude the state of Jammu \& Kashmir. 
Table 4

Muslim Legislators and Health Outcomes: Robustness Checks

\begin{tabular}{|c|c|c|c|c|c|c|c|c|}
\hline & \multicolumn{8}{|c|}{ Panel A: Infant Mortality } \\
\hline & $(1)$ & $(2)$ & $\begin{array}{c}\text { State-specific } \\
\text { trends } \\
(3) \\
\end{array}$ & $\begin{array}{c}\text { District-specific } \\
\text { trends } \\
(4) \\
\end{array}$ & $\begin{array}{c}\text { Including } \\
\text { Jammu \& } \\
\text { Kashmir } \\
\text { (5) }\end{array}$ & $\begin{array}{c}\text { Larger } \\
\text { sample } \\
(6) \\
\end{array}$ & $\begin{array}{l}\text { 3-year average } \\
\text { Muslim } \\
\text { representation } \\
\text { (7) }\end{array}$ & $\begin{array}{c}\text { Muslim } \\
\text { representation } 5 \\
\text { years after birth } \\
\text { (8) }\end{array}$ \\
\hline Fraction Muslim legislators in district & $\begin{array}{c}-12.857^{* *} \\
{[5.577]}\end{array}$ & $\begin{array}{l}-13.778 \\
{[8.690]}\end{array}$ & $\begin{array}{c}-16.141^{* *} \\
{[6.585]}\end{array}$ & $\begin{array}{l}-13.104 \\
{[8.156]}\end{array}$ & $\begin{array}{c}-16.332^{* *} \\
{[7.147]}\end{array}$ & $\begin{array}{l}-17.310^{* * *} \\
{[6.320]}\end{array}$ & $\begin{array}{c}-16.870^{* *} \\
{[7.372]}\end{array}$ & $\begin{array}{c}9.831 \\
{[6.019]}\end{array}$ \\
\hline Fraction Muslim legislators * Muslim household & $\begin{array}{c}1.12 \\
{[5.902]}\end{array}$ & $\begin{array}{c}-0.084 \\
{[14.309]}\end{array}$ & $\begin{array}{c}4.158 \\
{[9.271]}\end{array}$ & $\begin{array}{c}4.42 \\
{[9.265]}\end{array}$ & $\begin{array}{c}4.213 \\
{[10.015]}\end{array}$ & $\begin{array}{c}3.063 \\
{[6.815]}\end{array}$ & $\begin{array}{c}0.256 \\
{[10.177]}\end{array}$ & $\begin{array}{l}-7.964 \\
{[7.250]}\end{array}$ \\
\hline Muslim household & $\begin{array}{c}-1.441^{*} \\
{[0.742]}\end{array}$ & $\begin{array}{c}-1.299 \\
{[1.693]}\end{array}$ & $\begin{array}{c}-1.793 \\
{[1.117]}\end{array}$ & $\begin{array}{c}-1.8 \\
{[1.115]}\end{array}$ & $\begin{array}{c}-1.846 \\
{[1.304]}\end{array}$ & $\begin{array}{l}-1.780^{* *} \\
{[0.801]}\end{array}$ & $\begin{array}{c}-1.338 \\
{[1.230]}\end{array}$ & $\begin{array}{c}-0.644 \\
{[0.989]}\end{array}$ \\
\hline $\begin{array}{l}\text { R-squared } \\
\text { Observations }\end{array}$ & $\begin{array}{c}0.04 \\
128100\end{array}$ & $\begin{array}{c}0.04 \\
128100\end{array}$ & $\begin{array}{c}0.04 \\
128100\end{array}$ & $\begin{array}{c}0.05 \\
128100\end{array}$ & $\begin{array}{c}0.04 \\
132541 \\
\end{array}$ & $\begin{array}{c}0.05 \\
164832 \\
\end{array}$ & $\begin{array}{c}0.04 \\
127423\end{array}$ & $\begin{array}{c}0.05 \\
135710\end{array}$ \\
\hline & \multicolumn{8}{|c|}{ Panel B: Neo-natal Mortality } \\
\hline Fraction Muslim legislators in district & $\begin{array}{c}-10.273^{*} \\
{[5.246]}\end{array}$ & $\begin{array}{c}-8.024 \\
{[6.626]}\end{array}$ & $\begin{array}{c}-12.839 * * \\
{[5.192]}\end{array}$ & $\begin{array}{c}-10.008 \\
{[6.102]}\end{array}$ & $\begin{array}{c}-13.248 * * \\
{[5.592]}\end{array}$ & $\begin{array}{l}-10.277 * \\
{[5.848]}\end{array}$ & $\begin{array}{c}-10.675^{*} \\
{[6.434]}\end{array}$ & $\begin{array}{c}0.88 \\
{[5.513]}\end{array}$ \\
\hline Fraction Muslim legislators * Muslim household & $\begin{array}{c}2.043 \\
{[4.819]}\end{array}$ & $\begin{array}{c}4.386 \\
{[11.595]}\end{array}$ & $\begin{array}{c}6.632 \\
{[7.890]}\end{array}$ & $\begin{array}{c}7.405 \\
{[7.914]}\end{array}$ & $\begin{array}{c}7.796 \\
{[8.457]}\end{array}$ & $\begin{array}{c}4.908 \\
{[6.524]}\end{array}$ & $\begin{array}{c}2.573 \\
{[7.371]}\end{array}$ & $\begin{array}{l}-0.843 \\
{[5.276]}\end{array}$ \\
\hline Muslim household & $\begin{array}{c}-0.916 \\
{[0.586]}\end{array}$ & $\begin{array}{c}-1.194 \\
{[1.355]}\end{array}$ & $\begin{array}{c}-1.463 \\
{[0.930]}\end{array}$ & $\begin{array}{l}-1.561 * \\
{[0.933]}\end{array}$ & $\begin{array}{c}-1.71 \\
{[1.091]}\end{array}$ & $\begin{array}{c}-1.307^{*} \\
{[0.725]}\end{array}$ & $\begin{array}{c}-0.982 \\
{[0.879]}\end{array}$ & $\begin{array}{c}-0.692 \\
{[0.680]}\end{array}$ \\
\hline R-squared & 0.04 & 0.04 & 0.03 & 0.04 & 0.03 & 0.04 & 0.04 & 0.04 \\
\hline Observations & 128100 & 128100 & 128100 & 128100 & 132541 & 164832 & 127423 & 135710 \\
\hline Margin of victory & $3 \%$ & $1 \%$ & $2 \%$ & $2 \%$ & $2 \%$ & $2 \%$ & $2 \%$ & $2 \%$ \\
\hline
\end{tabular}

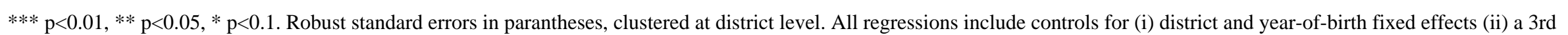

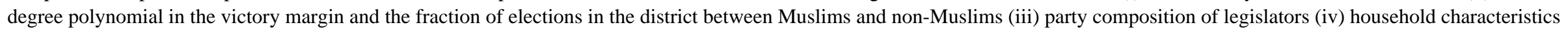

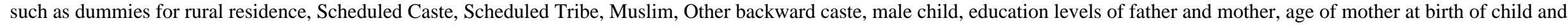

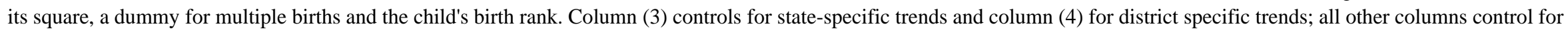
state*year fixed effects. Regressions exclude the state of Jammu \& Kashmir except in column (6). 
Table 5

Muslim Legislators and Education Outcomes: Robustness Checks

\begin{tabular}{|c|c|c|c|c|c|c|c|c|}
\hline & \multicolumn{8}{|c|}{ Panel A: Illiteracy } \\
\hline & $(1)$ & $(2)$ & $\begin{array}{l}\text { State- } \\
\text { specific } \\
\text { trends } \\
\text { (3) } \\
\end{array}$ & $\begin{array}{l}\text { District- } \\
\text { specific } \\
\text { trends } \\
(4) \\
\end{array}$ & $\begin{array}{l}\text { Including } \\
\text { Jammu \& } \\
\text { Kashmir } \\
\text { (5) } \\
\end{array}$ & $\begin{array}{c}\text { Larger } \\
\text { sample } \\
(6) \\
\end{array}$ & $\begin{array}{c}\text { Muslim } \\
\text { representation in } \\
\text { year before primary } \\
\text { (7) }\end{array}$ & $\begin{array}{c}\text { Muslim } \\
\text { representation } 5 \\
\text { years after started } \\
\text { primary } \\
\text { (8) } \\
\end{array}$ \\
\hline Fraction Muslim legislators in district in 3 years & $-0.212^{*}$ & -0.229 & $-0.265^{*}$ & $-0.341 * *$ & $-0.248^{*}$ & $-0.171^{*}$ & -0.187 & -0.052 \\
\hline before primary school & [0.113] & {$[0.201]$} & {$[0.145]$} & {$[0.161]$} & {$[0.143]$} & {$[0.094]$} & {$[0.129]$} & {$[0.157]$} \\
\hline Fraction Muslim legislators * Muslim household & $0.367 * *$ & 0.430 & 0.382 & 0.389 & 0.386 & $0.407^{*}$ & 0.293 & 0.02 \\
\hline & {$[0.186]$} & {$[0.492]$} & [0.289] & {$[0.282]$} & [0.295] & [0.223] & [0.341] & {$[0.252]$} \\
\hline Muslim household & $0.097 * * *$ & 0.089 & $0.095 * *$ & $0.094 * * *$ & $0.093 * *$ & $0.116^{* * *}$ & $0.107 * *$ & 0.142 \\
\hline & [0.025] & {$[0.064]$} & [0.037] & {$[0.036]$} & [0.038] & {$[0.026]$} & [0.043] & {$[0.031]$} \\
\hline R-squared & 0.22 & 0.22 & 0.22 & 0.22 & 0.22 & 0.27 & 0.22 & 0.24 \\
\hline \multirow[t]{2}{*}{ Observations } & 109448 & 109448 & 109448 & 109448 & 111827 & 203499 & 109448 & 66700 \\
\hline & \multicolumn{8}{|c|}{ Panel B: Years of primary school education } \\
\hline Fraction Muslim legislators in district in 3 years & $1.010^{*}$ & 1.274 & $1.379 *$ & $1.570 * *$ & $1.380^{*}$ & 0.194 & 0.532 & -0.112 \\
\hline before primary school & {$[0.580]$} & {$[1.014]$} & {$[0.754]$} & {$[0.783]$} & [0.733] & [0.118] & [0.599] & {$[0.244]$} \\
\hline \multirow[t]{2}{*}{ Fraction Muslim legislators * Muslim household } & -0.125 & $-0.756 * *$ & -0.055 & -0.222 & -0.064 & -0.364 & -1.398 & 0.023 \\
\hline & {$[0.244]$} & {$[0.367]$} & [0.289] & {$[0.301]$} & {$[0.286]$} & {$[0.246]$} & [1.536] & {$[0.244]$} \\
\hline \multirow[t]{2}{*}{ Muslim household } & $-0.634 * * *$ & $-0.566^{*}$ & $-0.614 * * *$ & $-0.607 * * *$ & $-0.604 * * *$ & $-0.161^{* * *}$ & $-0.681 * * *$ & -0.192 \\
\hline & [0.124] & [0.291] & [0.179] & {$[0.177]$} & [0.185] & {$[0.028]$} & [0.196] & {$[0.031]$} \\
\hline R-squared & 0.24 & 0.24 & 0.24 & 0.24 & 0.24 & 0.27 & 0.24 & 0.25 \\
\hline Observations & 109448 & 109448 & 109448 & 109448 & 111827 & 203499 & 109448 & 66700 \\
\hline Margin of victory & $3 \%$ & $1 \%$ & $2 \%$ & $2 \%$ & $2 \%$ & $2 \%$ & $2 \%$ & $2 \%$ \\
\hline
\end{tabular}

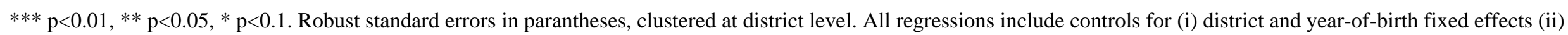

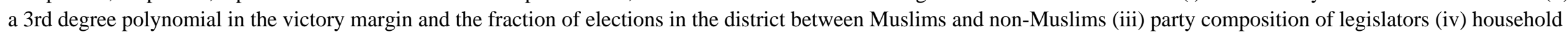

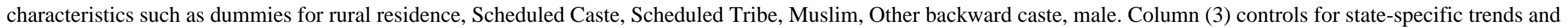
column (4) for district specific trends; all other columns control for state*year fixed effects. Regressions exclude the state of Jammu \& Kashmir except in column (6). 
Table A1

Muslim Legislators, Health and Education: OLS estimates

\begin{tabular}{|c|c|c|c|c|c|c|c|c|}
\hline & & & & & & & \multirow{2}{*}{\multicolumn{2}{|c|}{$\frac{\text { Years of primary school }}{\text { education }}$}} \\
\hline & \multicolumn{2}{|c|}{ Infant mortality } & \multicolumn{2}{|c|}{ Neo-natal mortality } & \multicolumn{2}{|c|}{ Illiteracy } & & \\
\hline & $(1)$ & $(2)$ & (3) & (4) & (5) & $(6)$ & (7) & (8) \\
\hline \multirow[t]{2}{*}{ Fraction Muslim legislators in district } & 0.536 & 0.053 & -0.33 & -0.777 & -0.031 & -0.070 & 0.015 & 0.039 \\
\hline & [1.727] & [1.791] & [1.552] & [1.588] & {$[0.040]$} & {$[0.047]$} & {$[0.044]$} & {$[0.050]$} \\
\hline \multirow[t]{2}{*}{ Fraction Muslim legislators * Muslim household } & & 1.77 & & 1.634 & & $0.142 * *$ & & -0.085 \\
\hline & & {$[1.440]$} & & [1.124] & & {$[0.069]$} & & {$[0.073]$} \\
\hline \multirow[t]{2}{*}{ Muslim household } & $-1.295 * * *$ & $-1.507 * * *$ & $-0.661 * * *$ & $-0.856 * * *$ & $0.144^{* * *}$ & $0.126^{* * *}$ & $-0.190 * *:$ & $-0.179 * * *$ \\
\hline & [0.321] & [0.370] & [0.254] & [0.286] & {$[0.011]$} & {$[0.012]$} & [0.012] & {$[0.014]$} \\
\hline R-squared & 0.04 & 0.04 & 0.04 & 0.04 & 0.22 & 0.22 & 0.22 & 0.22 \\
\hline Observations & 128100 & 128100 & 128100 & 128100 & 109448 & 109448 & 109448 & 109448 \\
\hline District and year-of-birth FE & $\mathrm{Y}$ & $\mathrm{Y}$ & $\mathrm{Y}$ & $\mathrm{Y}$ & $\mathrm{Y}$ & $\mathrm{Y}$ & $\mathrm{Y}$ & $\mathrm{Y}$ \\
\hline State*year-of-birth FE & $\mathrm{Y}$ & $\mathrm{Y}$ & $\mathrm{Y}$ & $\mathrm{Y}$ & $\mathrm{Y}$ & $\mathrm{Y}$ & $\mathrm{Y}$ & $\mathrm{Y}$ \\
\hline Party composition of legislators & $\mathrm{Y}$ & $\mathrm{Y}$ & $\mathrm{Y}$ & $\mathrm{Y}$ & $\mathrm{Y}$ & $\mathrm{Y}$ & $\mathrm{Y}$ & $\mathrm{Y}$ \\
\hline
\end{tabular}

${ }^{* * *} \mathrm{p}<0.01,{ }^{* *} \mathrm{p}<0.05,{ }^{*} \mathrm{p}<0.1$. Robust standard errors in parantheses, clustered at district level. All regressions include controls for household characteristics such as dummies for rural residence, Scheduled Caste, Scheduled Tribe, Muslim, Other backward caste, male, and health regressions additionnaly include: education levels of father and mother, age of mother at birth of child and its square, a dummy for multiple births and the child's birth rank. Regressions exclude the state of Jammu \& Kashmir. 
Table A2

First stage results for instrumental variables strategy

\begin{tabular}{lcc}
\hline & & Education \\
& Health outcomes & $\begin{array}{c}\text { outcomes } \\
\text { sample } \\
\text { sample }\end{array}$ \\
\cline { 2 - 3 } Fraction Muslim legislators in district & $(1)$ & $0.891^{\star \star \star}$ \\
& $0.874^{\star \star \star}$ & {$[0.156]$} \\
Fraction close elections between M & {$[0.067]$} & $-0.373^{\star \star \star}$ \\
and non-M in district & $-0.361^{\star \star \star}$ & {$[0.080]$} \\
Observations & {$[0.052]$} & 109448 \\
R-squared & & 0.94 \\
F-statistic & 128100 & 12.31 \\
& 0.93 & $\mathrm{Y}$ \\
District and year-of-birth FE & 167.61 & $\mathrm{Y}$ \\
State*year-of-birth FE & & $\mathrm{Y}$ \\
3rd degree polynomial in victory margin & $\mathrm{Y}$ & $\mathrm{Y}$ \\
Party composition of legislators & $\mathrm{Y}$ & $2 \%$ \\
Margin of victory & $\mathrm{Y}$ & $\mathrm{Y}$ \\
& $2 \%$ & \\
\hline
\end{tabular}

*** $\mathrm{p}<0.01,{ }^{* *} \mathrm{p}<0.05,{ }^{*} \mathrm{p}<0.1$. Robust standard errors in parantheses, clustered at district level.

All regressions include controls for household characteristics such as dummies for rural residence,

Scheduled Caste, Scheduled Tribe, Muslim, Other backward caste, male. Health sample regressions also include controls for the education levels of father and mother, age of mother at birth of child and its square, a dummy for multiple births and the child's birth rank. Regressions exclude the state of Jammu \& Kashmir. 
Table A3

Verifying that changes in covariates do not respond to instrumental variables

\begin{tabular}{|c|c|c|c|c|c|c|c|c|c|c|}
\hline \multirow[b]{3}{*}{ Fraction Muslim legislators in district } & \multicolumn{6}{|c|}{ Characteristics of household } & \multicolumn{4}{|c|}{ Characteristics of child } \\
\hline & $\begin{array}{c}\text { Muslim } \\
\text { (1) }\end{array}$ & $\begin{array}{l}\text { Non-Hindu } \\
\text { and non- } \\
\text { Muslim } \\
\text { (2) }\end{array}$ & $\begin{array}{l}\text { Scheduled } \\
\text { Caste } \\
\text { (3) }\end{array}$ & $\begin{array}{l}\text { Scheduled } \\
\text { Tribe } \\
(4)\end{array}$ & $\begin{array}{c}\text { Other } \\
\text { Backward } \\
\text { Caste } \\
\text { (5) }\end{array}$ & $\begin{array}{l}\text { Rural area } \\
(6)\end{array}$ & $\begin{array}{l}\text { Child is } \\
\text { male } \\
\text { (7) }\end{array}$ & $\begin{array}{l}\text { Age of mother } \\
\text { at birth of child } \\
\text { (8) }\end{array}$ & $\begin{array}{l}\text { Mother's } \\
\text { years of } \\
\text { education } \\
\text { (9) }\end{array}$ & $\begin{array}{c}\text { Father's } \\
\text { years of } \\
\text { education } \\
(10) \\
\end{array}$ \\
\hline & $\begin{array}{c}-0.032 \\
{[0.078]}\end{array}$ & $\begin{array}{c}0.041 \\
{[0.037]}\end{array}$ & $\begin{array}{c}0.115 \\
{[0.072]}\end{array}$ & $\begin{array}{c}-0.068 \\
{[0.041]}\end{array}$ & $\begin{array}{c}0.039 \\
{[0.080]}\end{array}$ & $\begin{array}{c}-0.004 \\
{[0.074]}\end{array}$ & $\begin{array}{c}0.025 \\
{[0.096]}\end{array}$ & $\begin{array}{c}1.972 \\
{[1.363]}\end{array}$ & $\begin{array}{c}-0.95 \\
{[0.677]}\end{array}$ & $\begin{array}{c}0.163 \\
{[1.017]}\end{array}$ \\
\hline $\begin{array}{l}\text { Fraction close elections between Muslims } \\
\text { and non-Muslims in district }\end{array}$ & $\begin{array}{c}0.01 \\
{[0.037]}\end{array}$ & $\begin{array}{c}-0.003 \\
{[0.015]}\end{array}$ & $\begin{array}{c}-0.070 * * \\
{[0.033]}\end{array}$ & $\begin{array}{c}0.057 * * \\
{[0.023]}\end{array}$ & $\begin{array}{c}0.045 \\
{[0.037]}\end{array}$ & $\begin{array}{c}0.012 \\
{[0.033]}\end{array}$ & $\begin{array}{c}0.045 \\
{[0.044]}\end{array}$ & $\begin{array}{c}0.541 \\
{[0.619]}\end{array}$ & $\begin{array}{c}0.033 \\
{[0.322]}\end{array}$ & $\begin{array}{c}-0.283 \\
{[0.531]}\end{array}$ \\
\hline $\begin{array}{l}\text { R-squared } \\
\text { Observations }\end{array}$ & $\begin{array}{c}0.22 \\
129694\end{array}$ & $\begin{array}{c}0.3 \\
129694\end{array}$ & $\begin{array}{c}0.07 \\
128389\end{array}$ & $\begin{array}{c}0.28 \\
128389\end{array}$ & $\begin{array}{c}0.18 \\
128389\end{array}$ & $\begin{array}{c}0.3 \\
129694\end{array}$ & $\begin{array}{c}0.01 \\
129694\end{array}$ & $\begin{array}{c}0.05 \\
129694\end{array}$ & $\begin{array}{c}0.21 \\
129638\end{array}$ & $\begin{array}{c}0.11 \\
129437\end{array}$ \\
\hline
\end{tabular}

*** $\mathrm{p}<0.01,{ }^{* *} \mathrm{p}<0.05, * \mathrm{p}<0.1$. Robust standard errors in parantheses, clustered at district level. All regressions include controls for (i) district and year-of-birth fixed effects (ii) a 3rd degree polynomial in the victory margin (iii) state*year fixed effects. Regressions exclude the state of Jammu \& Kashmir. 


\section{Table A4}

\section{Characteristics of close elections with Muslim and non-Muslim winners}

\begin{tabular}{lrrr}
\hline & $\begin{array}{r}\text { Winner is non- } \\
\text { Muslim }\end{array}$ & $\begin{array}{r}\text { Winner is } \\
\text { Muslim }\end{array}$ & $\begin{array}{r}\text { Difference } \\
\text { significant? }\end{array}$ \\
\cline { 2 - 4 } Winner is from Congress & 0.189 & 0.357 & $* *$ \\
Winner is from BJP & 0.315 & 0.020 & $* *$ \\
Winner is from Left parties & 0.099 & 0.122 & \\
Winner is from a national party & 0.613 & 0.551 \\
Winner is from a major party & 0.784 & 0.735 \\
Winner is an independent & 0.063 & 0.112 \\
Winner is a woman & 0.054 & 0.020 \\
Total number of candidates & 13.93 & 12.07 \\
Total votes cast in election & 88974 & 87960 \\
& & & \\
Observations & 111 & 98 & \\
\hline
\end{tabular}

Sample restricted to constituencies where the top two winners were a Muslim and a non-Muslim and the winner won by less than $2 \%$ of votes cast. $* * *$ indicates difference at $1 \%$ level, $* *$ at $5 \%$ level and $*$ at $1 \%$ level. Significance in differences calculated using a t-test. 
Figure 1. First stage illustration

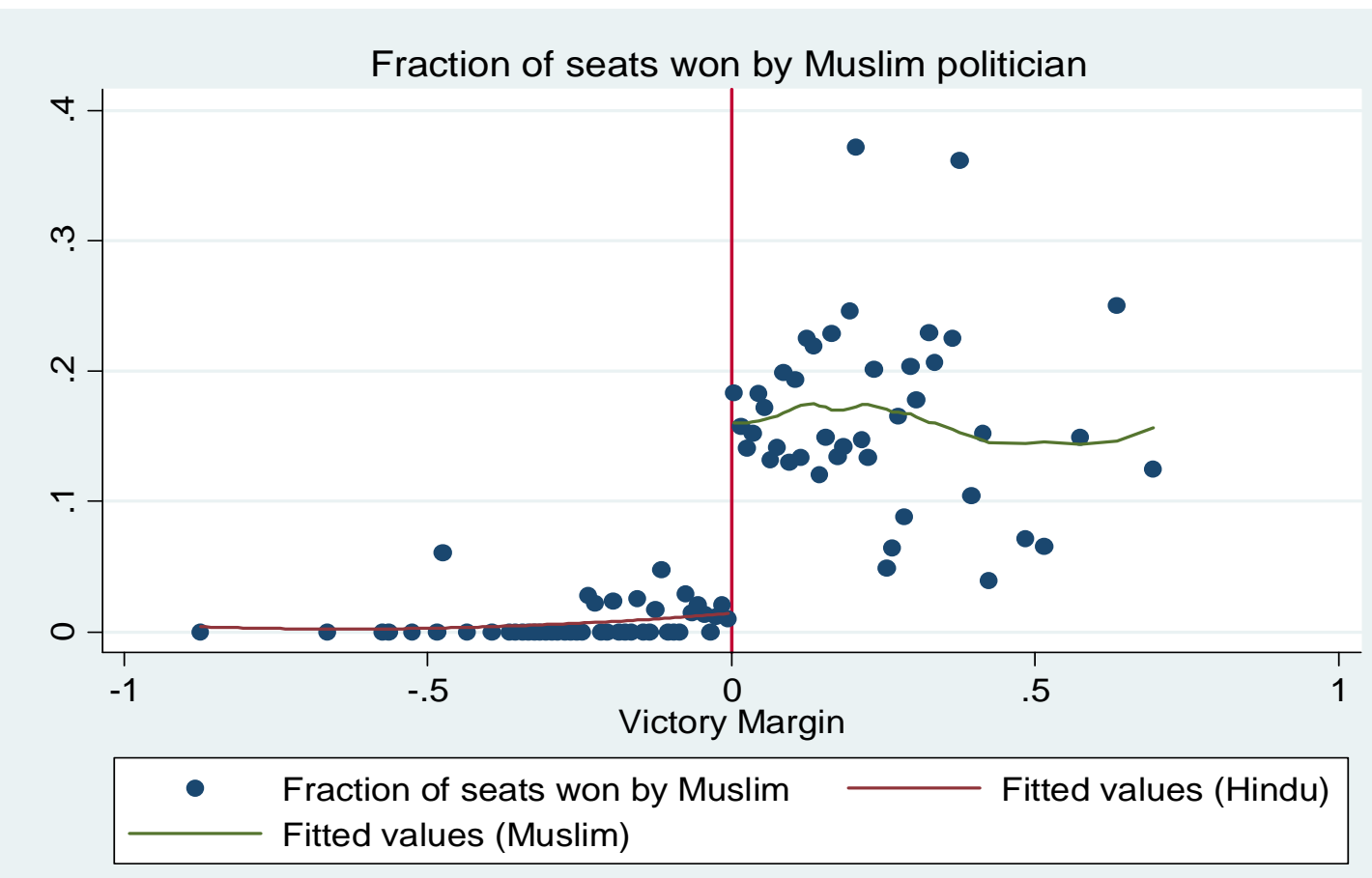

Data from 1977-1999 aggregated into 1 percentage point bins 
Figure 2. Continuity of the vote margin between Muslims and non-Muslims (running variable)
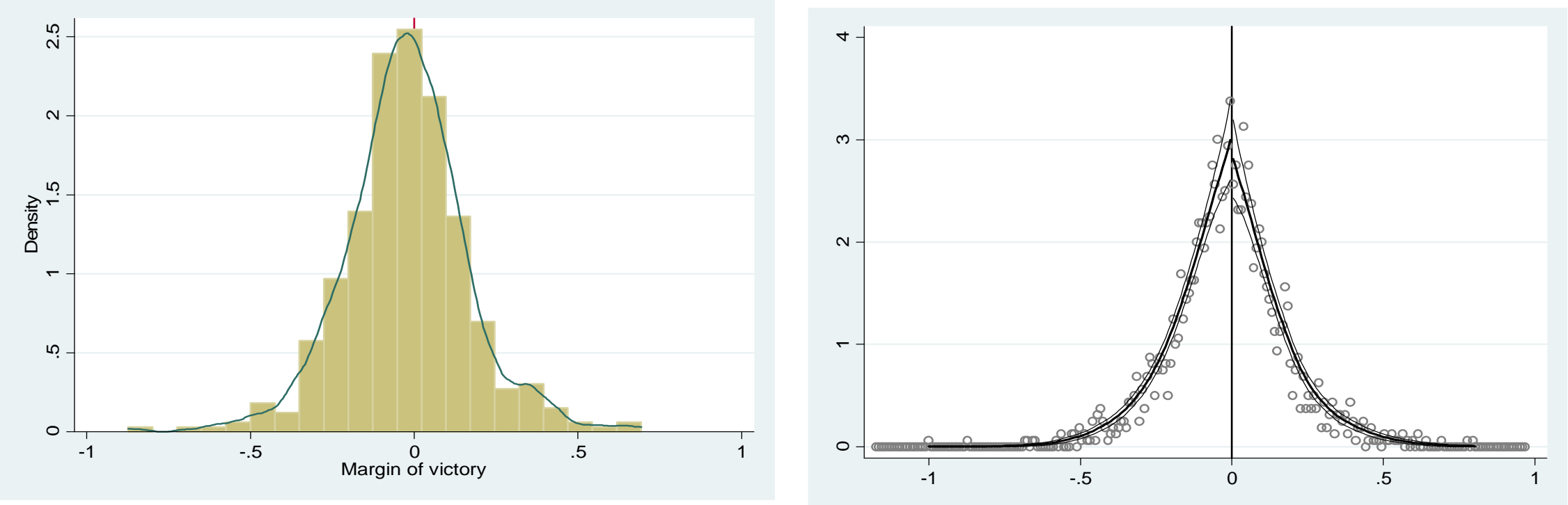

Log difference in height $-0.065(\mathrm{se}=0.1010)$ 